\title{
PENTINGNYA WAWASAN NUSANTARA UNTUK MELESTARIKAN \\ PERBEDAAN BUDAYA DI REA GLOBALISASI
}

\author{
Alya Tata Riani \\ Institut Ilmu Kesehatan STRADA Indonesia \\ alyatata456@gmail.com
}

\begin{abstract}
Abstrak
Wawasan nusantara merupakan suatu hal yang penting untuk dipahami oleh seluruh rakyat Indonesia. Akan tetapi, sangat disayangkan masih banyak masyarakat Indonesia yang memiliki wawasan nusantara yang rendah. Cara yang paling tepat untuk menanamkan konsep wawasan nusantara ini adalah tentang cara melestarikan perbedaan budaya dengan menyangkut pautkan wawsan Nusantara Era globalisasi dapat menimbulkan perubahan pola hidup masyarakat yang lebih modern. Akibatnya masyarakat cenderung untuk memilih kebudayaan baru yang dinilai lebih praktis dibandingkan dengan budaya lokal. Salah satu faktor yang menyebabkan budaya lokal dilupakan dimasa sekarang adalah; kurangnya generasi penerus yang memiliki minat untuk belajar dan mewarisi kebudayaanny sendiri. oleh karena itu wawasan Nusantara sangat dibutuhkan untuk menyakinkan bangsa Indonesia agar lebih menghargai kebudayaan di Indonesia, karena sangat banyak bermacam jenis kebudayaan di Indonesia
\end{abstract}

Kata kunci: wawsan Nusantara ,Indonesia, Budaya, Globalisasi, Masyarakat.

\section{Latar Belakang}

Di era globalisasi seperti sekarang ini, sudut-sudut dunia seakan-akan sangat dekat di kehidupan kita sehari-hari. Melalui teknologi komunikasi dan Informasi, dari sudut dunia manapun sangat mudah untuk kita ketahui. Akibatnya tanpa disadari difusi atau persebaran ide-ide, baik berupa sistem sosial ataupun budaya dari luar masuk ataupun masyarakat luar menyebar dan mungkin ikut terinternalisasi dalam kehidupan suatu masyarakat regional tertentu, seperti masyarakat suatu negara. Persebaran ide-ide tersebut, makin intens karena didukung oleh kemajuan teknologi informasi dan para penyedia informasi yang berlomba-lomba menginovasi diri sebagai penyedia jasa pemberi informasi. Pengaruh yang kompleks tersebut, sudah pasti mempengaruhi kehidupan masyarakat/bangsa suatu negara, tak terkecuali masyarakat dan bangsa Indonesia.Perkembangan globalisasi yang masuk, pada akhirnya akan mempengaruhi 
budaya yang ada.Pada saat pengaruh globalisasi mulai masuk pada budaya lokal, maka masyarakat akan dihadapkan pada pilihan apakah akan mengikuti pengaruh globalisasi atau akan tetap mempertahankan budaya yang ada. Jika masyarakat mempertahankan budaya lokal, melalui adat istiadat, norma, bahasa, kesenian, dengan baik maka tidak pengaruhi terhadap pengaruh luar.

Namun, sebaliknya jika nilai nilai budaya sudah mulai ditinggalkan maka masyarakat terpengaruh dengan budaya dari luar tersebut. Memahami budaya lokal sangat penting terutama dalam upaya untuk memahami karakteristik budaya setempat, perlu sikap saling menghargai dan menghormati budaya yang ada. Pada saat kita berbincang tentang perbedaan budaya, peran wawasan Nusantara sangat lah penting yaitu gina untuk Wawasan nusantara dalam bidang sosial budaya merupakan wawasan nusatara yang mengamati atau mempelajari segala sesuatu mengenai masyarakat atau kepentingan umum yang menggunakan pola pikir dengan mengandung cinta, rasa, dan karsa (budi, perasaan, dan kehendak).

Sesuai dengan sifatnya, kebudayaan merupakan warisan yang bersifat memaksa bagi masyarakat yang bersangkutan. Artinya setiap generasi yang lahir dari suatu masyarakat dengan serta merta mewarisi norma-norma budaya dari generasi sebelumnya. Proses sosial dalam upaya menjaga persatuan nasional sangat membutuhkan kesamaan persepsi atau kesatuan cara pandang diantara segenap masyarakat tentang eksistensi budaya yang sangat beragam namun memiliki semangat untuk membina kehidupan bersama secara harmonis.

\section{Khasus/Masalah}

Warga Indonesia reharusnya
mengetahui cara untuk melestarikan
kebudayaannya sediri, karena kebudayaan di
Indonesia sangat beragam, banyak cara
melestarikan kebudayaan di era globalisasi
Cotohnya dengan mengetahui wawasan
Nusantara.

\section{Tinjauan Pustaka}

a. pengertian budaya lokal

Pada dasarnya setiap manusia yang lahir kedunia ini hidup dan dibesarkan dalam budaya tertentu. Demikian pula dalam proses internalisasi budaya. Seseorang bisa mempelajari (diajari) disuruh menjalankan hal-hal yang baik dan menghindari hal yang dianggap buruk karena proses internalisasi dalam budaya masyarakat yang sudah meresap dan menjadi bagian dari hidup seseorang tersebut serta menjadi acuan dalam berpikir dan berperilaku. Sehingga, seseorang akan berperilaku serta bertindak karena pengaruh dari perilaku sesuai dengan kaidahkaidah yang berlaku. Misalnya jika ia dibesarkan dalam budaya Jawa maka ia akan bertingkah laku sesuai dengan kaidah-kaidah yang ada didalam budaya tersebut. Demikian pula jika seseorang dianggap harus bisa 
memahami budaya yang ada disekitarnya, maka dia pun harus bisa mengetahui bagaimana kaidahkaidah yang ada dalam budaya tersebut. Ketika dia bisa mempelajari kaidah budaya yang ada dalam masyarakat, maka dalam bertindak dan berperilaku pasti akan mengacu pada kaidah budaya yang ada. Begitupula jika ingin mengembangkan potensi budaya lokal makan peran komunikasi antar budaya harus dapat memahami adat istiadat, norma, yang berlaku dalam budaya tersebut.

\section{Menurut Zulyani}

Hidayah, terdapat lima ciri pengelompokan suku bangsa yang dapat disamakan dengan pengertian budaya lokal, yaitu :Pertama adanya komunikasi melalui bahasa dan dialek diantara mereka. Kedua, polapola sosial kebudayaan yang menimbulkan perilaku sebagai bagian dari kehidupan adat istiadat yang dihormati bersama. Ketiga,adanya perasaan keterikatan antara satu dengan yang lainnya sebagai suatu kelompok bagian yang menimbulkan rasa kebersamaan diantara mereka. Keempat, adanya kecenderungan menggolongkan diri ke kelompok asli terutama ketika menghadapi kelompok lain pada berbagai kejadian sosial kebudayaan. Kelima, adanya perasaaan keterikatan dalam kelompok karena hubungan kekerabatan, genealogis dan ikatan kesadaran teritorial diantara mereka.

b. Pengertian wawasan Nusantara

Wawasan Nusantara
adalah cara pandang bangsa
Indonesia terhadap rakyat,
bangsa, dan wilayah Negara
Kesatuan Republik Indonesia
yang meliputi darat, laut, dan
udara di atasnya sebagai satu
kesatuan politik, ekonomi, sosial,
budaya dan pertahanan
keamanan. Secara umum,
wawasan nusantara berfungsi
sebagai pedoman, motivasi,
dorongan, serta rambu-rambu
dalam menentukan segala jenis
kebijaksanaan, keputusan,
tindakan dan perbuatan bagi
penyelenggara Negara di tingkat
pusat dan daerah maupun bagi
seluruh rakyat Indonesia dalam
kehidupan bermasyarakat,
berbangsa, dan bernegara
Dalam hakikat wawasan
nusantara, tiap warga negara
tanpa kecuali harus berpikir,
bersikap, dan bertindak secara
utuh dan menyeluruh, semata-
mata demi kepentingan nasional.
Oleh sebab itu, hakikat wawasan
nusantara juga dapat diartikan
sebagai keutuhan serta kesatuan
wilayah nasional atau persatuan
bangsa dan wilayah.
pengertian komunikasi

Kata atau istilah “ komunikasi” (dari bahasa inggris "Communication") berasal dari 
"communicatus". Dalam bahasa Latin, yang artinya "berbagi" atau menjadi milik bersama. Dengan demikian, komunikasi menurut Lexicographer (ahli kamus bahasa) menunjuk pada suatu upaya yang bertujuan berbagi untuk mencapai kebersamaan. Sementara itu, dalam Webster's New Collegiate Dictionary edisi tahun 1977 komunikasi adalah "suatu proses pertukaran informasi diantara individu melalui sistem lambang-lambang, tanda-tanda atau tingkah laku."(Sasa Djuarsa, 1993 :7). Sedangkan, Menurut Hovland, Janis \& Kelley, Komunikasi adalah suatu proses melalui mana seseorang (komunikator) menyampaikan stimulus (biasanya dalam bentuk kata kata) dengan tujuan mengubah atau membentuk perilaku orang-orang lainnya (khalayak).

Menurut Saundra Hybels dan Richard L.Weafer,Komunikasi merupakan setiap proses pertukaran informasi, gagasan dan perasaan. Proses itu meliputi informasi yang disampaikan tidak hanya secara lisan dan tulisan, tetapi juga dengan bahasa tubuh, gaya maupun penampilan diri atau menggunakan alat bantu disekeliling kita untuk memperkaya sebuah pesan.(Alo Liliweri, $2002: 3$ )

Dari berbagai definisi dari para ahli mengenai komunikasi,komunikasi merupakan langkah untuk memahami dan menganalisi keterlibatan kita dalam komunikasi manusia. Kita tidak bisa lepas dari komunikasi karena komunikasi merupakan bagian dari kehidupan manusia. Komunikasi juga merupakan proses mengenai pembentukan, penyampaian, penerimaan dan pengolahan pesan. Dimana setiap pelaku komunikasi akan melakukan tindakan membentuk, menyampaikan, menerima dan mengolah pesan. Pesan ini dapat berupa pesan tertulis, lisan, gambar=gambar, gerak gerik atau tingkah laku dan berbagai bentuk tanda-tanda lainnya ( Sasa Djuarsa, 1993 : 9).

d. pengertian kebudayaan

Jika dilihat dari asal kata maka istilah kebudayaan berasal dari kata Sansekerta buddayah sebagai bentuk jamak dari buddhi yang berarti budi atau akal. Maka kebudayaan dapat diartikan "halhal yang bersangkutan dengan budi dan akal". Bahasa Inggrisnya adalah culture, sedangkan kata Latin adalah colereartinya mengolah, mengerjakan atau sebagai segaa daya dan usaha manusia mengubah alam. Dari pengertian ini dapat ditarik suatu definisi umum yang luas, bahwa kebudayaan adalah seluruh cara hidup suatu masyarakat, tidak hanya mengenaik cara hidup yang dianggap lebih tinggi atau diinginkan. Melihat batasan ini, kebudayaan berarti mencakup semua cara berpikir dan 
berperilaku manusia, mulai dari hal yang sederhana sampai dengan merancang sesuatu. Secara umum, kebudayaan adalah kehidupan manusia itu sendiri yang meliputi pikiran, karya dan hasil karyanya. Sedangkan, dalam arti sempit, kebudayaan diartikan dengan sesuatu yang indah atau seni, seperti lukisan, seni tari, musik dsbnya.(Sasa Djuarsa, 1993:186).

\section{Pembahasan}

Di era Globalisasi maka terjadi proses "penduniaan nilai nilai budaya" kehidupan dari suatu ruang budaya ke suatu ruang budaya ke ruang budaya lain. Proses penduniaan sebagai proses perubahan sosial yang cepat karena didukung oleh teknologi komunikasi yang memungkinkan kecepatan pertukaran pesan bisa melintasi ruang dan waktu. Sehingga, pesan-pesan yang dikirimkan itu berasal dari dan menuju ke sasaran penerima yang berbeda budayanya. Dampak dari globalisasi adalah dunia menjadi semakin sempit, bahkan dunia menjadi global village artinya dunia menjadi tidak ubahnya dengan desa, dimana interaksi antarbangsa didunia terlus berlangsung setiap waktu. Orang dari berbagai bangsa dengan latar belakang nilai-nilai, adat-istiadat, ideologi, keyakinan yang berbeda, bertemu dan berkomunikasi satu sama lain, baik untuk hubungan ekonomi, sosial, politik dan keamanan. Oleh sebab itu, setiap bangsa harus memahami budaya bangsa lain untuk menciptakan hubungan antarnegara secara saling menguntungkan Untuk tetap mengembangkan budaya lokal, kita harus menjaga bahasa lokal yang ada di daerah tersebut.

Misalnya dalam Bahasa Jawa mengenal undhak undhuk basa dan menjadi bagian integral dalam tata krama masyarakat Jawa. Di surakarta, terdapat bentuk bagongan dan kedhaton yang dipakai sebagai bahasa pengantar di lingkungan keraton. Dalam bahasa Jawa, terdapat tiga bentuk utama variasi, yaitu ngoko ("kasar"), madya ("biasa"), dan krama ("halus"). Di antara masingmasing bentuk ini terdapat bentuk "penghormatan" (ngajengake, honorific) dan "perendahan" (ngasorake, humilific). Seseorang dapat berubahubah registernya pada suatu saat tergantung status yang bersangkutan dan lawan bicara. Status bisa ditentukan oleh usia, posisi sosial, atau hal-hal lain. Seorang anak yang bercakap-cakap dengan sebayanya akan berbicara dengan varian ngoko, namun ketika bercakap dengan orang tuanya akan menggunakan krama andhap dan krama inggil. Sistem semacam ini terutama dipakai di Surakarta, Yogyakarta, dan Madiun. Untuk dapat terus mengembangkan budaya lokal, maka jika mengacu pada unsurunsur wawasan Nusantara.

Implementasi wawasan nusantara dalam kehidupan sosial budaya, akan menciptakan sikap yang mengakui, menerima dan juga menghormati segala bentuk perbedaan atau keBhinekaan sebagai 
kenyataan hidup sekaligus karunia Sang Pencipta agar tercipta juga suasana yang aman dan nyaman di negara Indonesia ini.

\section{Kesimpulan .}

Salah satu cara untuk mempertahankan budaya lokal yang ada adalah melalui bahasa, karena bahasa selalu digunakan untuk berinteraksi serta berkomunikasi dengan orang lain. Pemahaman untuk memahami bahasa menjadi salah satu unsur dalam komunikasi antar budaya. Selain itu, perlu adanya Kesadaran pribadi, yaitu setiap individu harus memahami bahwa setiap individu pada dasarnya mempunyai kepribadian, kecenderungan dan kebiasaan (tingkah laku) masing-masing. Dalam keluarga pasti perbedaan kebudayaan pribadi dapat ditemuai. Namun, jika ada rasa saling menghargai, saling memahami akan adanya perbedaan budaya akan mempererat hubungan yang ada. Ini artinya, jika ingin tetap mempertahankan budaya lokal, kesadaran pribadi menjadi hal penting. Harus ada rasa saling menghargai dan menghormati satu dengan yang lain, Kesadaran domestik, yaitu dengan makin besarnya peluang setiap orang untuk berinteraksi dengan orang lain yang memiliki kebudayaan yang berbeda, dan Kesadaran Internasional, yaitu dengan semakin canggihnya teknologi komunikasi dan informasi, maka pengaruh dari luar baik hal yang positif dan hal negatif bisa masuk. Namun dengan tetap mempertahankan budaya lokal maka pengaruh negatif dari globalisasi tidak akan berpengaruh terhadap budaya setempat. 


\section{Daftar Pustaka}

Sodik, M. A., \& Nzilibili, S. M. M. (2017). The Role Of Health Promotion And Family Support With Attitude Of Couples Childbearing Age In Following Family Planning Program In Health. Journal of Global Research in Public Health, 2(2), 82-89.

TAHIN, M. W., \& Sodik, M. A. (2021). Pengaruh Merokok Bagi Remaja Terhadap Perilaku dan Pergaulan Sehari-hari.

Riani, A. T. SOLIDARITAS MAHASISWA DALAM MEMPERKOKOH PERSATUAN DAN KESATUAN BANGSA INDONESIA.

Danusaputro, M. (1982). Wawasan Nusantara.

Salampessy, Z., Triyuwono, I., Irianto, G., \& Hariadi, B. (2018). Pancasila paradigm: Methodology of wawasan nusantara for accounting of pancasila. Australasian Accounting, Business and Finance Journal, 12(1), 102-115. 